\title{
KEINTIMAN KOMUNIKASI MANUSIA DAN KOMPUTER DALAM FILM "HER"
}

\author{
Zainuddin Muda Z. Monggilo \\ Departemen Ilmu Komunikasi/Fakultas Ilmu Sosial \& Ilmu Politik, Universitas Gadjah Mada, Indonesia \\ Email: zainuddinmuda19@ugm.ac.id
}

\begin{abstract}
ABSTRAK
Masalah penelitian adalah bagaimana kemesraan komunikasi terlihat dalam kisah film "Her". Tujuannya adalah untuk menggambarkan kecenderungan keintiman antara manusia dan komputer dalam film "Her". Film ini dipilih karena konsep dan ide cerita yang unik dan menarik serta serangkaian prestasi yang telah dicapai berdasarkan kualitas dan keuntungan penjualan di seluruh dunia. Sampel penelitian ini adalah 28 sekuen dengan fokus pada urutan yang mengandung interaksi antara Theodore dan Samantha sebagai dua karakter utama. Data dikumpulkan melalui observasi, dokumentasi, dan studi pustaka dengan metode analisis isi kuantitatif. Penelitian ini terbatas pada fungsi nyata dari objek penelitian. Hasil penelitian menunjukkan bahwa: (i) keintiman komunikasi yang paling dominan dalam film adalah keintiman pada tingkat stabilisasi (56\%), diikuti oleh efektif (19,5\%), orientasi dan eksplorasi (9,8\%), dan depenetrasi (4,9\%), (ii) keintiman komunikasi yang paling dominan, yang ditampilkan dalam film adalah komunikasi intensif (22\%) dan diikuti oleh topik pribadi (stabilisasi) (17\%), status konfirmasi (15\%), dan topik pribadi (eksplorasi) (10\%).
\end{abstract}

Kata kunci: analisis kandungan kuantitatif, film "Her”, keintiman komunikasi, teknologi komputer

\section{PENDAHULUAN}

Film "Her" berlatar waktu 2025, ketika manusia dan teknologi (komputer) digambarkan sebagai dua relasi yang tidak terpisahkan, saling membutuhkan satu sama lain. Film ini berkisah tentang seorang priabernama Theodore yang kesepianmenjelang perceraiannya. Di sela waktu luangnya sebagai penulis surat di sebuah perusahaan persuratan virtual, ia habiskan dengan bermain game dan sesekali bergaul bersama teman dan kerabat. Di tengah rutinitasnya itu, dia tertarik untuk membeli komputer baru yang bernama Operating System 1 (OS1), yang diklaim sebagai sistem operasi cerdas pertama di dunia. "Ini bukan hanya sebuah sistem operasi, ini sebuah kesadaran," kata tag line dari iklan OS1 tersebut. Theodore begitu tertarik dengan perangkat komputer baru yang dibelinya itu-Samantha namanya. Seiring waktu, mereka menjadi lebih dekat hingga akhirnya jatuh cinta satu sama lain. Samantha memang terbukti memiliki kecerdasan yang luar biasa dalam membantu pekerjaan Theodore. Namun demikian, tidak dalam menangani rasa cinta Theodore yang dirasakan kepadanya-yang notabene sebuah komputer.

Film ini menunjukkan bagaimana seorang manusia yang sebagian besar hidupnya digantungkan pada sebuah teknologi komputer dapat terjebak dalam suatu hubungan yang tidak biasa dengan teknologi itu sendiri. Suatu hubungan yang bukan sebatas relasi antara pemilik dan benda yang dimiliki, melainkan hubungan yang dekat dan akrab selayaknya dua anak manusia yang saling berinteraksi. Sebuah komputer tidak hanya mampu berfungsi sebagai perangkat keras teknologi yang membantu memudahkan pekerjaan manusia, tetapi komputer yang juga bertransformasi menjadi human-like machine yang mengambil porsi yang besar dan setara dalam kehidupan manusia, mempunyai ikatan emosional yang tinggi dengan penggunanya bahkan dikatakan berjenis kelamin perempuan atau laki-laki.

Cerita film ini sedianya tidak bisa dipandang sebelah mata sebagai film yang tidak membawa pesan moral bagi penontonnya. Jika ditelisik dengan lebih jeli dan saksama, penceritaannya yang imajinatif dan visioner sejatinya adalah prediksi tentang masa depan ketika manusia dan teknologi sudah hampir berada pada posisi yang setara khususnya dalam hal kemampuan berkomunikasi dan berpikir. Manusia dan komputer dalam film ini bisa menjadi teman kerja, teman main, atau kekasih intim pada saat yang bersamaan. Singkat kata, bukan tidak mungkin bahwa nantinya interaksi manusia dan teknologi akan terbentuk selayaknya interaksi dalam kehidupan bernyawa (Reeves \& Nass, 1996, p.5). 
Berangkat dari hal tersebut, penulis mengajukan pertanyaan mengenai bagaimana keintiman komunikasi yang terjalin antara manusia dan komputer yang digambarkan dalam film "Her"? Penelitian dilakukan untuk mendeskripsikan keintiman komunikasi antara manusia dan komputer yang ditampilkan dalam film ini. Hasilnya diharapkan dapat memberikan informasi dan pengetahuan tentang keintiman komunikasi dalam konteks manusia dan teknologi secara spesifik, serta menjadi acuan metodologis bagi mereka yang ingin melaksanakan penelitian selanjutnya.

\section{Tinjauan Pustaka}

Mendefinisikan Keintiman. Keintiman berasal dari bahasa latin intimus yang artinya terdalam. Keintiman adalah kedekatan yang dirasakan oleh dua orang dan ikatan ini yang mengikat keduanya bersama (Baron \& Byrne, 2004, p. 28). Erikson mendefinisikan keintiman sebagai perasaan saling percaya, terbuka, dan saling berbagi dalam suatu hubungan (Kroger, 2001). Keintiman yang paling dasar dimulai ketika seorang individu telah mengenal dirinya dan merasa cukup aman dengan identitasnya sendiri (Erikson dalam Shaffer, 2005). Individu yang telah mencapai tahapan keintiman mampu berkomitmen pada pilihan yang telah diambilnya walaupun mengharuskan pengorbanan untuk mempertahankannya (Erikson dalam Marcia, Matteson, Archer, \& Orlofsky, 1993).

Orlofsky mendefinisikan keintiman sebagai kemampuan untuk membentuk dan mempertahankan hubungan yang intim atau akrab, yang biasanya terlihat dalam bentuk kedekatan, penghargaan terhadap individualitas, keterbukaan, komunikasi, tanggung jawab, hubungan timbal balik, komitmen dan seksualitas (Marcia, Matteson, Archer, \& Orlofsky, 1993). Seksualitas dalam hal ini tidak mengacu pada hubungan seks, tetapi lebih kepada kepuasan yang dirasakan individu dalam berinteraksi dengan orang lain.

Berdasarkan beberapa definisi tersebut dapat disarikan bahwa keintiman hubungan yang dekat atau akrab dengan orang lain ditunjukkan melalui rasa saling percaya, saling berbagi (keterbukaan diri), timbal balik (resiprositas) dan komitmen yang tinggi.

Keintiman dalam Teori Penetrasi Sosial. Terdapat kesesuaian antara permasalahan dalam penelitian dan teori penetrasi sosial yang dikembangkan oleh Irwin Altman dan Dalmas Taylor pada tahun 1973 yang berupaya memahami keintiman yang terjalin antara dua individu. Meskipun konteks keintiman yang diterangkan oleh Altman dan Taylor menekankan pada keintiman antarmanusiabukan manusia dan komputer-tetapi penulis mengidentifikasi adanya kesamaan yang digambarkan oleh teori ini tentang konsep pembentukan keintiman seperti yang dikisahkan dalam film "Her".

Di samping itu, pada bagian ini juga akan ditunjukkan perbedaan kontras antara teori pertukaran sosial dan teori penetrasi sosial yang memang mempengaruhi satu sama lain-konsep kunci dalam penetrasi sosial cenderung dipengaruhi oleh konsep kunci dari teori pertukaran sosial. Teori penetrasi sosial pun mampu secara runut menjelaskan tahapan pembentukan hubungan yang intim sebagaimana yang akan diteliti dalam film "Her". Atas dasar ini penulis memilih teori ini sebagai payung dalam menjabarkan konsep keintiman yang selanjutnya dapat dijabarkan dalam bentuk unit-unit analisis penelitian.

\section{a. Asumsi dan Konsep Tentang Keintiman dan Keterbukaan Diri (Self-Disclosure)}

Teori penetrasi sosial sendiri berdiri pada konteks komunikasi antarpribadi yang berasumsi bahwa seiring perkembangannya, hubungan bergerak dari komunikasi interpersonal yang relatif dangkal dan tidak intim ke tingkat yang lebih dalam dan intim (Griffin, 2012, pp. 113-114).

Keintiman yang terjadi merupakan hasil dari adanya keterbukaan diri dan pengembangan kedekatan. Teori ini percaya bahwa hanya melalui keterbukaan diri, seseorang dapat mengembangkan hubungan yang erat dengan orang lain. Pada awal hubungan terdapat suatu kaidah timbal balik yang kuat, yaitu pada saat seseorang mulai mengungkapkan halhal mengenai dirinya, pasangannya akan dengan sendirinya melakukan hal yang sama. Dengan demikian, kepercayaan satu sama lain mulai tertanam dan keintiman terbentuk (Griffin, 2012, p. 114).

Teori penetrasi sosial juga dikenal dengan analogi lapisan bawang dalam melihat kepribadian manusia sehingga terkadang disebut sebagai teori kepribadian bawang. Kepribadian seseorang diibaratkan seperti bawang yang berlapis-lapis dengan identitas diri yang sifatnya paling publik pada lapisan 
luar dan identitas diri yang paling pribadi pada lapisan intinya. Seiring berjalannya waktu dan tumbuhnya keintiman, lapisan kepribadian seseorang mulai terungkap satu demi satu hingga menunjukkan bagian paling terdalamnya (West \& Turner, 2010, p. 173).

\section{b. Teori Pertukaran Sosial dalam Teori Penetrasi Sosial}

Dari sudut pandang ilmiah, untuk mengambarkan penetrasi sosialnya, Altman dan Taylor meminjam konsep teori pertukaran sosial dari Thibaut dan Kelley tentang hasil (outcomes) relasional, kepuasan relasional, dan stabilitas relasional. Pinjaman konsep ini yang kemudian menjadi dasar dari format pengukuran yang dibuat oleh Altman dan Taylor yaitu rewards dikurangi costs, tingkat perbandingan, dan tingkat perbandingan alternatif (Griffin, 2012, pp. 117-119).

Pertama, perhitungan rewards dan costs, teori penetrasi sosial menyatakan bahwa manusia akan menimbang untung dan rugi atau positif dan negatif dari setiap hubungan dan interaksi yang dilakukannya dengan manusia lain. Jika interaksi cukup memuaskan, maka individu atau hubungan tersebut dianggap menguntungkan dan bernilai positif. Tapi jika interaksi tidak memuaskan, maka hubungan akan dievaluasi kembali terhadap costs atau ongkos yang dikeluarkan dalam membangun hubungan tersebut. Melalui pertimbangan seperti ini, individu mencoba untuk memprediksi hasil dari interaksi sebelum interaksi benar-benar dilakukan. Kontinuitas suatu hubungan ditentukan dari hasil yang diperoleh dari pengurangan rewardsterhadap costs. Hubungan akan berlanjut ketika hasil yang diperoleh positif - ditandai dengan nilai rewards yang tinggi. Rewards yang relatif lebih banyak diterima selanjutnya akan berkorelasi pada tingkat keterbukaan yang lebih besar dan keintiman yang lebih dalam. Sebaliknya, pada hubungan dengan costs yang relatif lebih banyak dikeluarkan - hasil bernilai negatif, akan berdampak pada terhentinya hubungan sehingga menghasilkan derajat keterbukaan yang lebih kecil dan keintiman yang dangkal (Griffin, 2012, pp. 117-118).

Kedua, tingkat perbandingan adalah standar yang digunakan untuk mengevaluasi kepuasan dari suatu hubungan. Pengalaman masa lalu dianggap dapat membentuk pikiran dan perasaan tentang pengembangan hubungan yang baru. Seseorang akan cenderung berkaca pada pengalaman masa lalu sebagai patokan untuk menentukan tingkat kepuasan hubungannya dengan orang yang lain (Griffin, 2012, pp. 118-119).

Ketiga, tingkat perbandingan alternatif adalah standar untuk mengevaluasi stabilitas dari hubungan. Pada dasarnya, tingkat perbandingan alternatif diukur dengan hasil terburuk yang diterima seseorang dengan tetap menjalankan suatu hubungan. Dengan kata lain, seseorang cenderung memilih untuk tetap melanjutkan hubungan meskipun dengan hasil buruk atas pertimbangan bahwa hal tersebut akan jauh lebih baik daripada melakukan pengandaian atas hasil baik yang belum tentu terjadi (Griffin, 2012, p. 119).

\section{c. Teori Penetrasi Sosial Bukan Pertukaran Sosial}

Sekilas keduanya tampak sama, tetapi sesungguhnya berbeda. Benar bahwa konsep rewards dan costs, tingkat perbandingan, dan tingkat perbandingan alternatif adalah tiga konsep yang dipedomani oleh teori penetrasi sosial dari tiga konsep teori pertukaran sosial yaitu outcomes, kepuasan hubungan, dan stabilitas hubungan. Namun, hal yang paling mendasar yang membedakan kedua teori ini adalah terletak pada fokusnya dalam menilai keterbukaan dan keintiman. Teori penetrasi sosial menekankan fokusnya pada keterbukaan diri yang berimplikasi pada keintiman hubungan dengan faktor-faktor hasrat dan emosi yang menyertainya, sedangkan teori pertukaran sosial mengesampingkan atau meniadakan aspek emosi serta mengutamakan rasionalitas dalam hubungan karena menurutnya hubungan tercipta sebagai suatu proses negosiasi yang melibatkan nilai-nilai ekonomi yang sangat dominan.

Kedua teori ini sedianya dapat digunakan untuk menjelaskan fenomena dalam penelitian ini. Namun demikian, teori penetrasi sosial lebih relevan karena kedekatannya dalam menjelaskan terbentuknya keintiman sebagaimana yang dimaksud dalam penelitian ini. Konteks keintiman dalam penelitian ini tidak terbentuk karena adanya perhitungan matematis untung dan rugi, tetapi terjadi melalui keterbukaan diri dan pengembangan hubungan secara emosional.

Hal lain yang juga perlu digarisbawahi ialah bahwa teori penetrasi sosial berada pada ranah teori yang objektif, berparadigma positivistik 
dan bersumber pada data empiris melalui eksperimen dan bukan semata dari kesimpulan pengalaman spesifik individu. Walaupun teori ini terkesan memiliki konsepsi yang sederhana dan meminjam beberapa pokok pemikiran dari penetrasi sosial, teori ini tetap mampu menghadirkan tahapantahapan yang prosedural untuk mendukung argumenargumennya sendiri secara ilmiah-demikian halnya dalam menjelaskan tahapan keintiman dalam penelitian ini.

\section{d. Tahapan Pembentukan Hubungan (Keintiman)}

Tingkat keintiman dibagi ke dalam dua indikator yaitu kedalaman (depth) dan keluasan (breadth). Kedalaman adalah tingkat pengungkapan pada area spesifik dari kehidupan individu (Griffin, 2012, p. 115, West \& Turner, 2010, p. 172). Keluasan adalah berbagai bidang dalam kehidupan individu di mana pengungkapan berlangsung (Griffin, 2012, p. 117 , West \& Turner, 2010, p. 173). Dari hal ini dapat dipahami bahwa kedalaman merujuk kepada tingkat keintiman sedangkan keluasan merujuk pada berbagai topik yang didiskusikan dalam suatu hubungan. Keduanya memegang peranan yang krusial dalam proses penetrasi sosial. Singkatnya, suatu keintiman membutuhkan keluasan dan kedalaman sebagai syaratnya.

Kedalaman dan keluasan ini kemudian yang mendasari lima tahapan keintiman atau disebut juga dengan tahapan penetrasi sosial: orientasi, penjajakan afektif, afektif, stabil, dan depenetrasi. Pertama, orientasi adalah tahap paling awal yang terjadi pada tingkat publik dan hanya sedikit mengenai diri kita yang terbuka untuk orang lain. Pada tahap ini kita terlibat dalam pembicaraan kecil dan sederhana dengan mengikuti standar norma kepatutan. Kedua, penjajakan afektif merupakan perluasan area publik dan terjadi ketika aspek-aspek privat dari kepribadian seorang individu akan muncul menjadi bagian dari publik. Ketiga, afektif yang dicirikan dengan interaksi yang lebih santai dan tanpa beban, komunikasi sering kali berjalan spontan dan individu membuat keputusan yang cepat, sering kali dengan sedikit memberikan perhatian untuk hubungan secara keseluruhan. Tahap ini menggambarkan komitmen lebih lanjut kepada individu lainnya; mulai timbul rasa nyaman antara satu sama lain. Keempat, stabil yaitu tahapan yang berhubungan dengan pengungkapan pemikiran, perasaan dan perilaku secara terbuka yang mengakibatkan munculnya spontanitas dan keunikan hubungan yang tinggi. Pada tahap ini kedekatan berada pada level yang sangat tinggi sehingga akan merangsang keintiman yang sangat tinggi pula. Hal ini karena masing-masing individu dapat melakukan prediksi secara akurat mengenai perilaku pasangannya. Kelima, depenetrasi (opsional) yaitu ketika hubungan mulai rusak dan costs melebihi rewards, maka ada penarikan dari pengungkapan diri yang mengarah ke pemutusan hubungan.

Sebagai penguat tahapan penetrasi tersebut, Ruben (1992, pp. 334-339) melengkapinya menjadi enam tahapan pembentukan hubungan. Pertama, inisiasi yaitu fase ketika dua atau beberapa individu mencatat dan menyesuaikan perilakunya satu sama lain. Selama inisiasi, individu yang terlibat dalam interaksi cenderung akan membawa kerangka pengalaman dan pengetahuan yang ia peroleh sebelumnya. Kedua, eksplorasi yaitu penjajakan potensi dan kemungkinan dalam membentuk hubungan lebih lanjut dengan individu lainnya. Pada fase ini, individu mengumpulkan informasi tentang kerangka, gaya, motif, kepentingan, dan nilainilai lain dari individu lainnya. Kumpulan informasi ini berfungsi sebagai dasar untuk menilaikemanfaatan dari keberlanjutan hubungan. Ketiga, yaitu jika hubungan berlanjut, bergerak ke fase ketiga yang disebut sebagai intensifikasi oleh Mark Knapp (Ruben, 1992:336). Pada tahap ini, individu-individu dihadapkan pada keputusan untuk melanjutkan hubungan. Seiring berlanjutnya hubungan, kumpulan informasi dari fase eksplorasi akan menjadi kumpulan pengetahuan yang pada saat bersamaan akan digunakan untuk membuat sejumlah aturan bersama, bahasa bersama, dankarakteristik hubungan. Suatu hubungan mungkin akan tertunda, memburuk, atau terus berlanjut. Keempat, formalisasi yaitu seiring waktu, berkembangnya hubungan mengembangkan kekhasan yang membedakannya dalam hal substil dan tidak substil dari kebanyakan hubungan lain yang pernah melibatkan individu-individu tersebut. Pada tahap ini, pengakuan simbolik adalah ikatan formal dalam hubungan. Dalam hubungan asmara misalnya, ikatan formal dapat berupa pertunangan atau pernikahan; dalam hubungan pekerjaan, kontrak kerja adalah formalitas yang mengikat pekerjanya. Kelima, redefinisi yaitu dengan 
berlalunya waktu, individu pasti tumbuh dan berkembang sehingga menciptakan tekanan untuk perubahan pada individu dan hubungan itu sendiri. Akibatnya, kebutuhan untuk mendefinisikan beberapa aturan hubungan bersamasering muncul. Ketika perubahan terjadi terlalu cepat atau ekstrim, atau resistensi terlalu besar, proses kerusakan hubungan dimulai. Keenam, deteriorasi terjadi ketika hubungan telah mencapai tahap kerusakan, hal-hal yang pernah disepakati dan dibagi bersama sudah tidak ada lagi. Akibatnya sangat mungkin terjadi pemutusan hubungan karena dari setiap individu yang terlibat dalam hubungan telah berbeda satu sama lain.

Tahapan pembentukan keintiman tersebut yang dijadikan sebagai unit analisis penelitian dalam proses identifikasi keintiman manusia dan komputer dalam film "Her". Secara berurutan, tahapan keintiman yang diteliti dalam penelitian ini adalah tahapan perkenalan, penjajakan, pengungkapan, pemeliharaan, dan pemutusan.

Studi Terkait Keintiman dan Keterbukaan

Diri. Salah satu kelebihan teori penetrasi sosial dibandingkan dengan pertukaran sosial adalah keluasan kajiannya yang dapat diterapkan pada bentuk-bentuk hubungan sosial yang tercipta melalui Computer-Mediated Communication (CMC) atau media interaktif. Beberapa penelitian terdahulu telah mengaplikasikan teori penetrasi sosial ini untuk mengkaji aspek-aspek hubungan antar manusia melalui media komputer/interaktif (internet).

Survei yang pernah dilakukan berkaitan dengan jejaring sosial seperti Facebook, MySpace, Twitter, LinkedIn, dll berkontribusi cukup signifikan terhadap interaksi antara manusia. Mengambil Facebook sebagai contoh, pengguna dapat menentukan tingkat dan derajat keterbukaan diri mereka dengan menetapkan pengaturan privasi mereka (McCarthy, 2009). Orang-orang cenderung menyampaikan informasi yang tidak bersifat pribadi ke permukaan dan mengembangkan hubungan intim yang mendalam dengan mengirimkan pesan Facebook secara pribadi atau membuat kelompok tertutup.

Penelitian lain yang dilakukan terkait dengan online dating. Adapun mengenai hubungan seksual, beberapa ahli berpendapat bahwa ketika memulai suatu hubungan romantis, ada perbedaan penting antara situs kencan internet dan ruang lainnya, seperti kedalaman dan luasnya informasi diri yang diungkapkan sebelum melangkah lebih jauh ke percakapan serius (Whitty, 2008, pp. 1707-1723).

Studi lain kemudian dilakukan pada pengaruh yang ditimbulkan dari blog dan online chatting yang mulai marak bermunculan di seluruh dunia terhadap proses komunikasi interpersonal. Menurut Jih-Hsin Tang dan Cheng-Chung Wang, blogger cenderung memiliki pola yang berbeda secara signifikan dari pengungkapan diri untuk khalayak target yang berbeda. Survei secara online yang melibatkan 1027 blogger Taiwan memeriksa kedalaman yang diungkapkan oleh blogger kepada khalayak online, sahabat dan orang tua serta sembilan topik lainnya yang diungkap (Yang, Yang, \& Chiou, 2010). Mengenai online chatting, penelitian yang dilakukan oleh Dietz Uhle, Uskup Clark dan Howard menunjukkan bahwa sekali norma pengungkapan atau keterbukaan diri terbentuk, maka norma tersebut diperkuat oleh pernyataan-pernyataan yang mendukung keterbukaan diri (Dietz-uhler, BishopClark, Howard, 2005, pp. 114-120).

Studi yang telah dilakukan tersebut tentu tidak terlepas dari kritik atau keterbatasan yang dimilikinya. Salah satu yang luput dari analisis adalah adanya kemungkinan bahwa seseorang bisa menipu orang lain tentang identitas dirinya karena ada lebih banyak kesempatan melakukannya tanpa ada aturan yang membuat pelaku merasa khawatir atau bersalah di dunia maya. Seseorang bisa saja merekayasa dirinya dalam interaksinya dengan orang lain dan pada saatnya menciptakan hubungan interpersonal dikemas dengan kepalsuan yang mungkin juga menimbulkan kedekatan dan keintiman yang fiktif.

Terlepas dari keterbatasannya melihat kebenaran identitas tersebut, studi yang telah ada tetap menunjukkan adanya kemungkinan-kemungkinan yang tersedia dalam penelitian yang menyangkut dengan keterbukaan dan keintiman, tidak hanya dalam realitas sosial, tetapi juga realitas maya yang berkembang melalui media interaktif. Hal ini semakin mengukuhkan posisi teori ini sebagai panduan dalam mendeskripsikan keintiman yang terbentuk antara manusia dan komputer dalam film "Her".

\section{BAHAN DAN METODE PENELITIAN}

Penelitian ini berparadigma positivistik dengan mengedepankan pendekatan kuantitatif yang objektif, dianalisis secara deskriptif dan apa adanya (manifest) 
guna menyimpulkan secara umum melalui pengamatan empiris terhadap masalah yang diteliti. Sumber data dalam penelitian berasal dari data primer yang diperoleh secara langsung dari rekaman film "Her" dan data sekunder yang diperoleh dari berbagai literatur, jurnal ilmiah atau dokumen lain sebagai penunjangnya. Data-data tersebut dikumpulkan dengan cara observasi-dokumentasi (pengamatan sequence demi sequence film) dan studi kepustakaan (melalui pencarian data pustaka yang berupa buku, majalah, jurnal, informasi website, dll untuk menemukan penjelasan pendukung yang relevan dengan objek penelitian.

Fokus penelitian adalah keintiman komunikasi manusia dan komputer yang ditampilkan film "Her" garapan sutradara Spike Jonze, berdurasi 126 menit, berjenis drama romantis dan sains ilmiah, dan diperankan oleh aktor dan aktris ternama seperti Joaquin Phoenix, Amy Adams, Scarlett Johansson, dan Olivia Wilde. Di samping para pemerannya yang populer, film ini dipilih karena konsep dan ide ceritanya yang unik dan tidak biasa atas penggambarannya terhadap bentuk keintiman yang tercipta antara manusia dan komputer di masa depan. Selain itu, film ini juga telah mencetak banyak prestasi dari segi kualitas maupun keuntungan penjualan di seluruh dunia. Film ini telah memenangkan 37 penghargaan sejak penayangannya tahun 2013 antara lain Best Orginal Screenplay dari Academy Awards 86, Best Screenplay pada Golden Globe Awards 71, Best Film dan Best Director pada National Board of Review Awards, dan Top 10 Film tahun 2013 oleh American Film Institute. Dari segi penjualan, film meraup keuntungan sebesar US $\$ 44$ juta, dua kali lipat melebihi dari ongkos produksi sebesar US\$23 juta (IMDB, n.d.).

Keseluruhan adegan dalam film "Her" adalah populasi dalam penelitian. Sedangkan unit adegan yang menjadi sampel adalah sequence yaitu kumpulan scene yang bisa mengandung berbagai lokasi dan berakhir ketika ada pergantian karakter atau cerita yang sudah tidak berkesinambungan (Heyes, 2012). Total sampel sequence yang diteliti berjumlah 28 babak. Penentuan sampel ini dilakukan secara purposif dengan maksud menyesuaikan dengan tujuan penelitian yang hendak dicapai.

Teknik analisis yang digunakan dalam penelitian ini adalah analisis isi kuantitatif untuk mendeksripsikan secara objektif, sistematik, dan kuantitatif terhadap apa yang tampak dari suatu konten komunikasi (Berelson, 1952, p.18). Analisis data dibagi ke dalam lima unit kategori yaitu tahapan tahapan pengenalan, tahapan penjajakan/ pendekatan, tahapan pengungkapan, tahapan pemeliharaan dan tahapan pemutusan. Analisis data tersebut dilakukan dengan dengan menghitung frekuensi kemunculan keintiman komunikasi dalam sampel sequence per unit kategori. Koefisien reliabilitas Holsti 0,7-1 (70\%-100\%) diterapkan untuk menentukan kelayakan pemahaman terhadap definisi operasional unit analisis sehingga hasil yang diperoleh terpercaya.

\section{HASIL DAN PEMBAHASAN}

a. Tahapan pengenalan (orientasi/inisiasi)

Pada tahapan ini komunikasi berlangsung pada konteks umum dengan pembicaraan sederhana, normatif dan tertutup. Tahapan pengenalan dicirikan dengan tegur sapa sederhana, topik pembicaraan normatif, dan komunikasi tertutup. Hasil pengamatan dari 28 sequence diperoleh bahwa:

\section{Tabel 1. Orientasi/Inisiasi}

\begin{tabular}{|c|c|c|c|}
\hline Unit Analisis & $\begin{array}{c}\text { Sequence } \\
\text { Kemunculan }\end{array}$ & Frekuensi & $\begin{array}{c}\text { Persentase } \\
(\%)\end{array}$ \\
\hline $\begin{array}{l}\text { 1. Tegur Sapa } \\
\text { Sederhana }\end{array}$ & 4 & 1 & 25 \\
\hline $\begin{array}{l}\text { 2. Topik Pem- } \\
\text { bicaraan } \\
\text { Normatif }\end{array}$ & $4 \& 5$ & 2 & 50 \\
\hline $\begin{array}{l}\text { 3. Komunikasi } \\
\text { Tertutup }\end{array}$ & 4 & 1 & 25 \\
\hline Total & 2 & 4 & 100 \\
\hline
\end{tabular}

Penggalan adegan dalam sequence 4 menit 13.27-14.10 yang terkait dengan tegur sapa sederhana yang dilakukan oleh Theodore dan Samantha pada awal perkenalan dapat dilihat pada gambar 1 .

Cuplikan adegan dalam sequence 5 menit 16.3118.40 ketika Theodore dan Samantha membicarakan topik normatif yang berhubungan dengan pekerjaan dapat dilihat pada gambar 2 .

\section{b. Tahap penjajakan/pendekatan (eksplorasi)}

Komunikasi sudah mulai bergerak ke arah yang lebih khusus dalam suasana yang mulai mencair dan terbuka terhadap hal-hal yang sifatnya personal. 

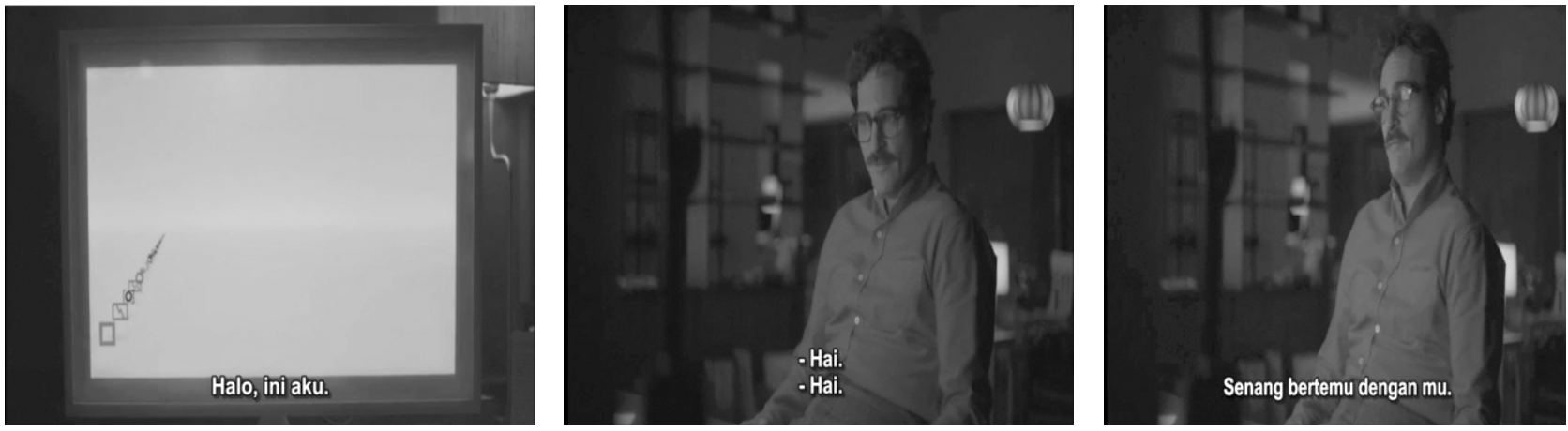

Gambar 1. Theodore dan Samantha ketika baru pertama kali berkenalan
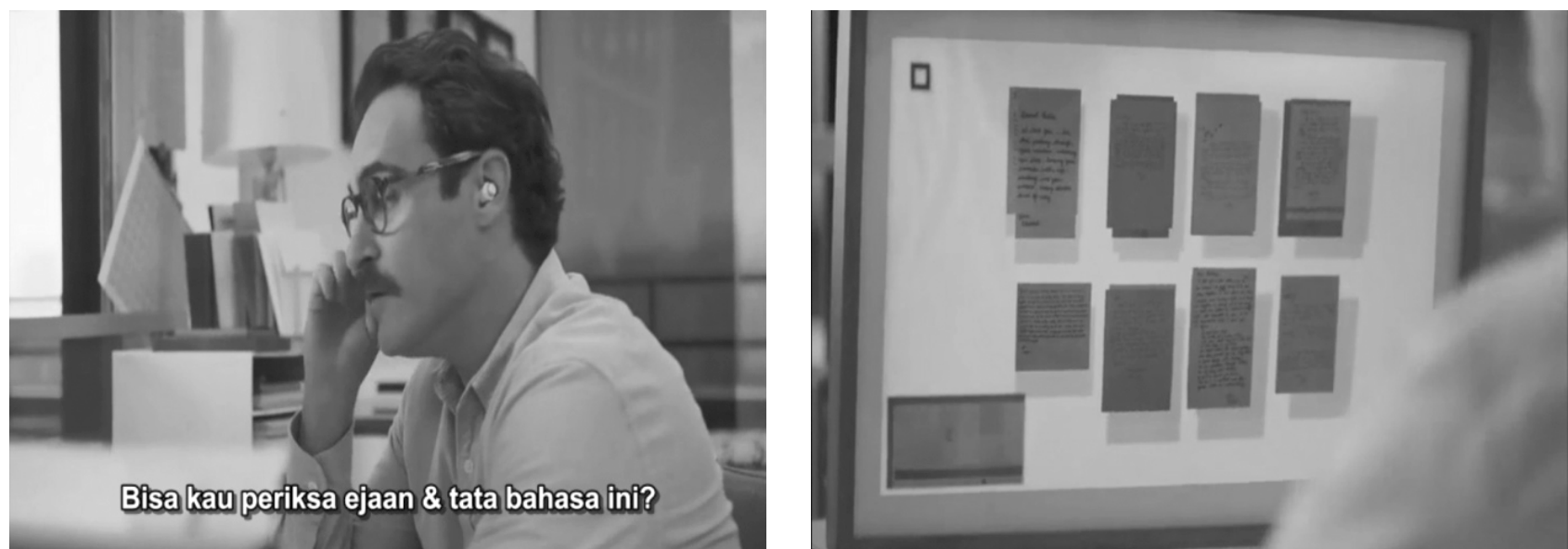

Gambar 2. Theodore yang meminta bantuan Samantha melakukan koreksi tata bahasa

Tahapan ini dibagi menjadi topik pembicaraan ke arah personal dan komunikasi mulai terbuka. Hasil perhitungan diperoleh:

\section{Tabel 2. Eksplorasi}

\begin{tabular}{cccc}
\hline Unit Analisis & $\begin{array}{c}\text { Sequence } \\
\text { Kemunculan }\end{array}$ & Frekuensi & $\begin{array}{c}\text { Persentase } \\
(\%)\end{array}$ \\
\hline Topik & $7,8,10$ & 3 & 75 \\
$\begin{array}{c}\text { Pembicaraan ke } \\
\text { Arah Personal } \\
\text { Komunikasi } \\
\text { Mulai Terbuka }\end{array}$ & 7 & 1 & 25 \\
\hline Total & 3 & 4 & 100 \\
\hline
\end{tabular}

Potongan adegan dalam sequence 7 menit 20.05-23.20 ketika Theodore dan Samantha membicarakan topik yang mulai mengarah pada ranah yang privat dapat dilihat pada gambar 3 . Pada tahap ini komunikasi secara tidak langsung akan mulai lebih fleksibel dan terbuka. c. Tahap pengungkapan (afektif/intensifikasi)

Tahapan ini didefinisikan dengan komunikasi yang mengarah pada pernyataan pemikiran, perasaan, dan pengambilan keputusan secara sadar dan terbuka untuk melanjutkan hubungan ke jenjang yang lebih serius. Pembagian tahapan ini terdiri dari topik pembicaraan personal, pengungkapan perasaan dan komunikasi intim. Hasil perhitungannya diilustrasikan sebagai berikut:

\section{Tabel 3. Afektif/Intensifikasi}

\begin{tabular}{lccc}
\hline \multicolumn{1}{c}{ Unit Analisis } & $\begin{array}{c}\text { Sequence } \\
\text { Kemunculan }\end{array}$ & Frekuensi & $\begin{array}{c}\text { Persentase } \\
(\%)\end{array}$ \\
\hline $\begin{array}{l}\text { Topik } \\
\text { Pembicaraan }\end{array}$ & $10,11,13$, & 4 & 50 \\
$\begin{array}{l}\text { Personal } \\
\text { Pengungkapan }\end{array}$ & 14 & & \\
$\begin{array}{l}\text { Perasaan } \\
\text { Komunikasi Intim }\end{array}$ & 13 & 3 & 37,5 \\
\hline \multicolumn{1}{c}{ Total } & 4 & 1 & 12,5 \\
\hline
\end{tabular}



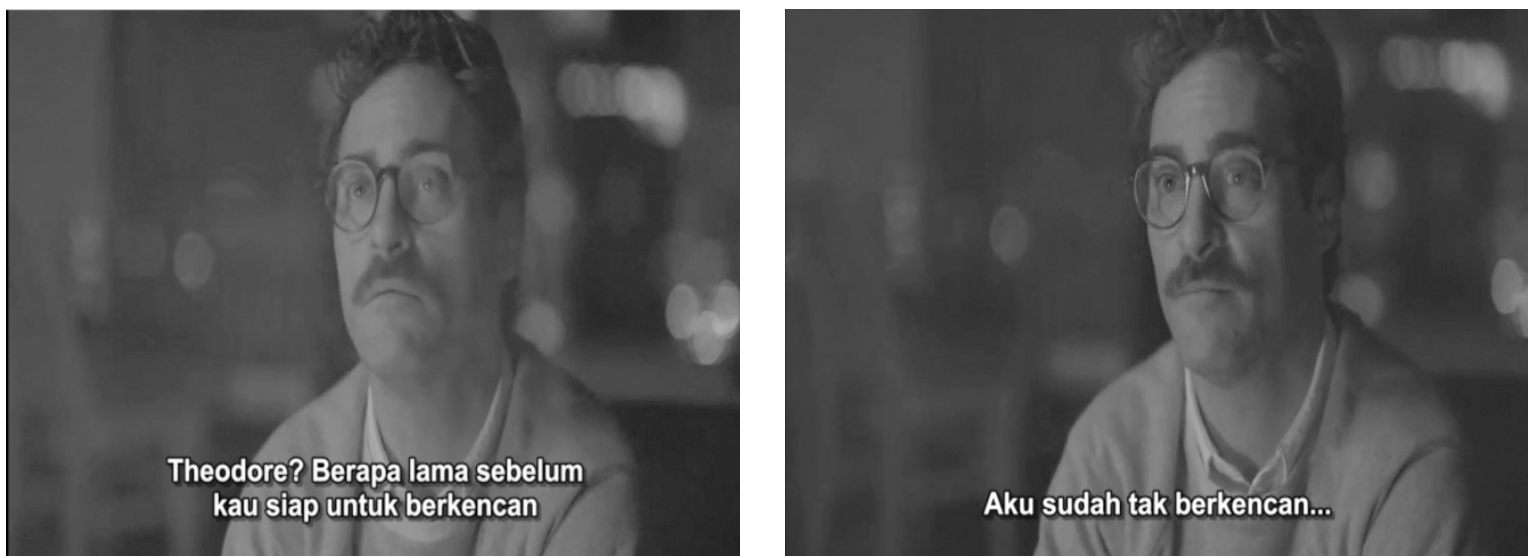

Gambar 3. Theodore ketika ditanya Samantha tentang hubungan asmaranya
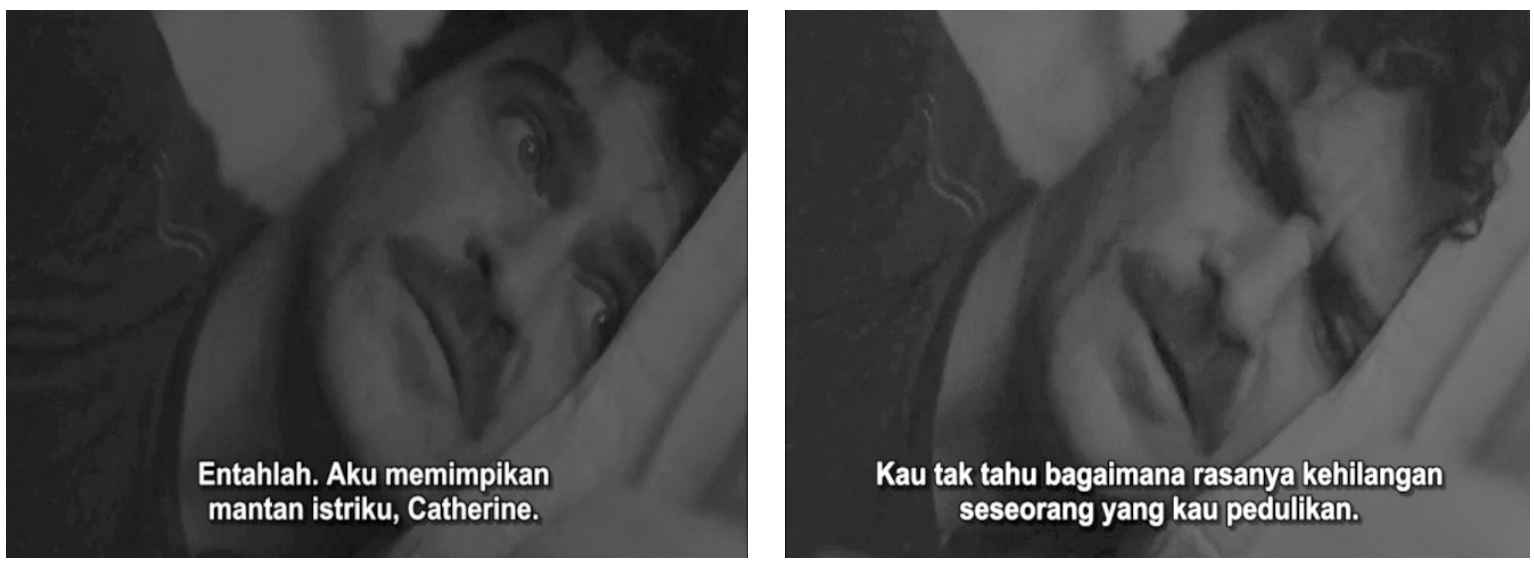

Gambar 4. Theodore ketika berbagi cerita tentang perceraiannya dengan mantan istrinya
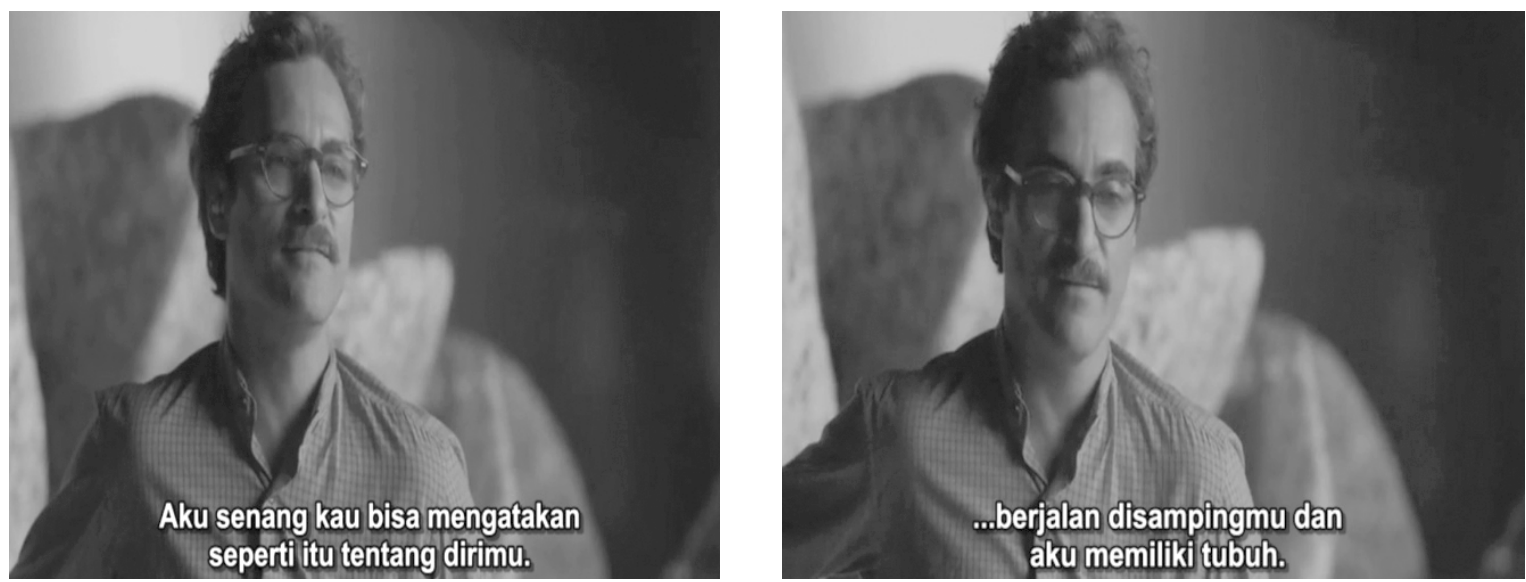

Gambar 5. Theodore dan Samantha yang bercerita tentang perasaan masing-masing dalam suasana yang akrab

Penggalan adegan dalam sequence 10 menit 26.3729.33 ketika Theodore dan Samantha membicarakan tentang problem perceraian yang tengah dihadapi Theodore dapat dilihat pada gambar 4 .

Potongan adegan dalam sequence 13 menit 29.34-33.06 ketika Theodore dan Samantha saling mengungkapkan perasaan mereka masing-masing dapat dilihat pada gambar 5 .

Cuplikan adegan dalam sequence 13 menit 42.31-44.24 ketika Theodore dan Samantha terlibat dalam komunikasi yang intim dapat dilihat pada gambar 6. 


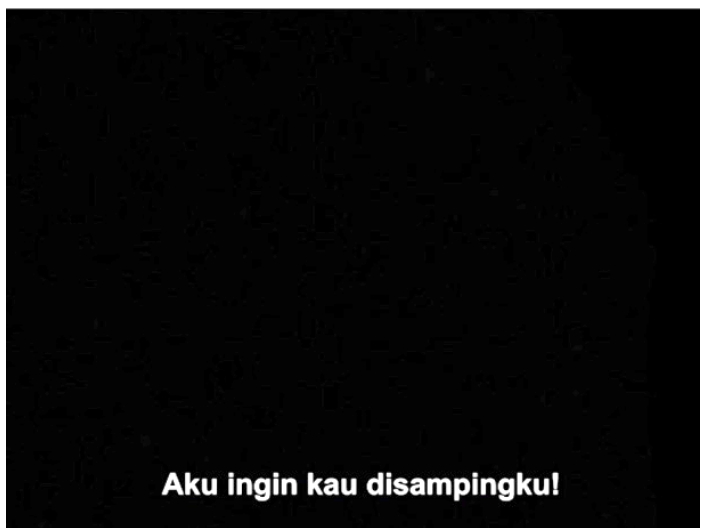

Gambar 6. Theodore dan Samantha ketika pertama kalinya melakukan virtual sex

\section{d. Tahap pemeliharaan (stabilisasi/formalisasi)}

Tahapan pemeliharaan ditandai dengan komunikasi yang dilakukan untuk mempertahankan hubungan yang telah dibangun dan menjaga kedekatan dan keintiman yang sudah dibangun. Tahapan pemeliharaan ini hampir sama dengan tahapan pengungkapan yang dicirikan dengan komunikasi intensif, pengukuhan status dan hubungan intim. Hasil perhitungan ditemukan bahwa:

\section{Tabel 4. Stabilisasi/Formalisasi}

\begin{tabular}{|c|c|c|c|}
\hline Unit Analisis & $\begin{array}{c}\text { Sequence } \\
\text { Kemunculan }\end{array}$ & Frekuensi & $\begin{array}{c}\text { Persentase } \\
(\%)\end{array}$ \\
\hline Topik & $17,18,19$ & 7 & 30,43 \\
\hline Pembicaraan & $20,22,25$ & & \\
\hline Personal & 26 & & \\
\hline Komunikasi & $17-22,24-26$ & 9 & 39,13 \\
\hline Intensif & & & \\
\hline Pengukuhan & $17,18,19$, & 6 & 26,09 \\
\hline Status & $22,25,26$ & & \\
\hline Hubungan Intim & 22 & 1 & 4,34 \\
\hline Total & 9 & 23 & 100 \\
\hline
\end{tabular}

Masih sama dengan tahapan pengungkapan, tahapan ini juga didominasi oleh topik pembicaraan yang personal dalam komunikasi yang intensif. Gambar 7-8 adalah contoh adegan dalam sequence 17 menit 56.52-58.09 dan sequence 18 menit 58.10-59.49 ketika Samantha menanyakan tentang hubungan antara Theodore dengan sahabatnya Amy dan Samantha yang dikenalkan sebagai pacar kepada anak angkat Theodore.

Gambat 9 adalah penggalan sequence 22 jam 1.16.38-1.20.08 ketika Samantha mencari tubuh pengganti agar bisa merasakan mempunyai tubuh dan berhubungan intim dengan Theodore.

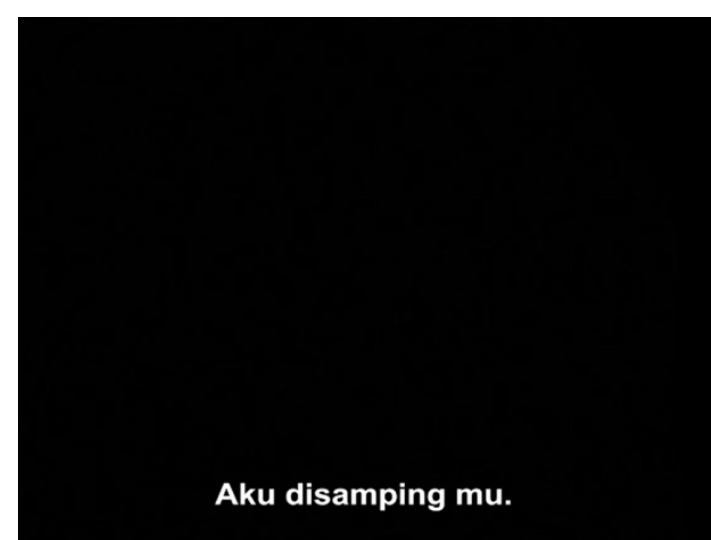

e. Tahap pemutusan (depenetrasi/deteriorasi)

Pada tahap ini komunikasi kehilangan kendali sehingga hubungan mengarah pada kondisi yang tidak bisa lagi dipertahankan. Ciri utama dari tahapan ini adalah terjadinya komunikasi satu arah dan pemutusan status hubungan. Hasil perhitungan menunjukkan bahwa:

Tabel 5. Depenetrasi/Deteriorasi

\begin{tabular}{lccc}
\hline \multicolumn{1}{c}{ Unit Analisis } & $\begin{array}{c}\text { Sequence } \\
\text { Kemunculan }\end{array}$ & Frekuensi & $\begin{array}{c}\text { Persentase } \\
(\%)\end{array}$ \\
\hline $\begin{array}{l}\text { Komunikasi Satu } \\
\text { Arah }\end{array}$ & 28 & 1 & 50 \\
Pemutusan Status & 28 & 1 & 50 \\
\hline \multicolumn{1}{c}{ Total } & 1 & 2 & 100 \\
\hline
\end{tabular}

Gambar 10-12 adalah contoh adegan dalam sequence 28 jam 1.42.35-1.48.20 ketika Samantha akhirnya harus pergi dan memutuskan hubungannya dengan Theodore.

Secara keseluruhan temuan data yang diperoleh dapat diilustrasikan pada grafik 1 (adapun data akumulasi frekuensi masing-masing unit analisis terlampir).

Mengacu pada data yang diperoleh maka dapat dimaknai bahwa keintiman komunikasi yang paling banyak ditonjolkan dalam film ini adalah keintiman yang berada pada tingkat stabilisasi $(56 \%)$ kemudian disusul oleh tingkat afektif $(19,5 \%)$, orientasi dan eksplorasi $(9,8 \%)$ serta ditutup dengan depenetrasi (4,9\%). Kemudian bila dikaitkan dengan urutan kemunculan sequencenya, maka dapat diketahui bahwa alur penceritaan film selaras dengan alur pembentukan keintiman yang diadopsi dari tahapan penetrasi sosial Altman dan 

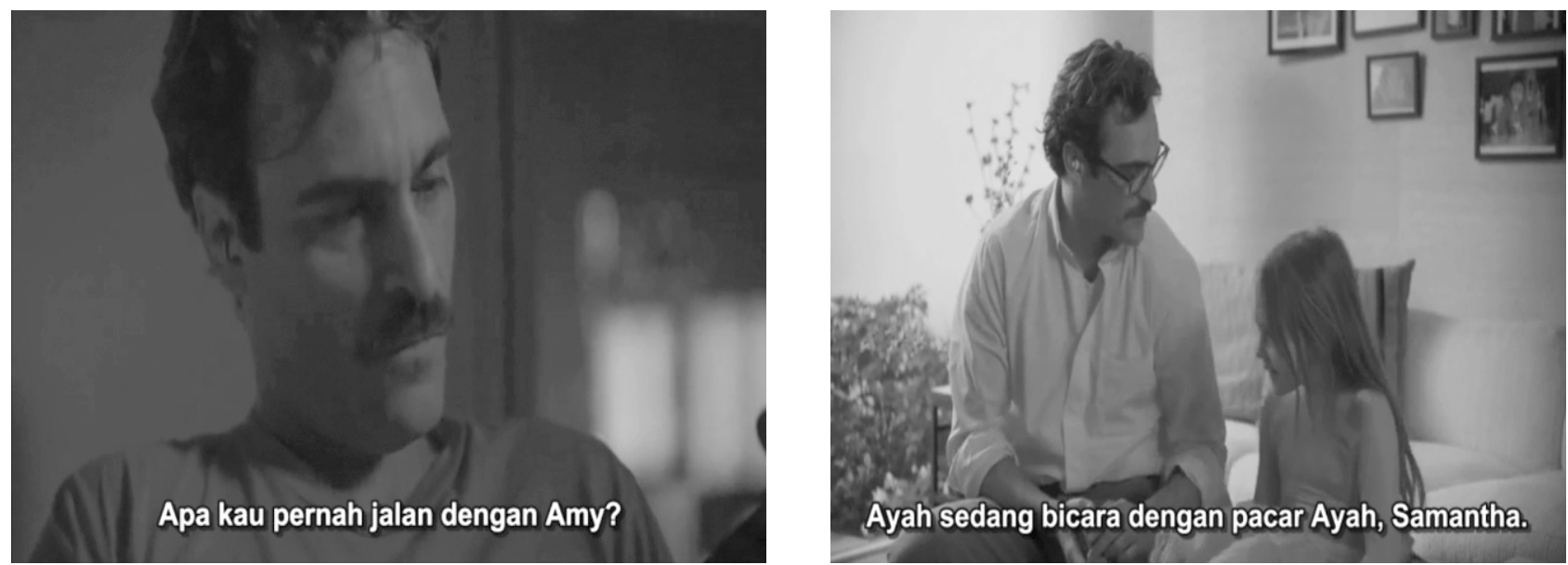

Gambar 7-8. Samantha yang cemburu dengan Amy dan Samantha yang langsung akrab dengan putri angkat Theodore
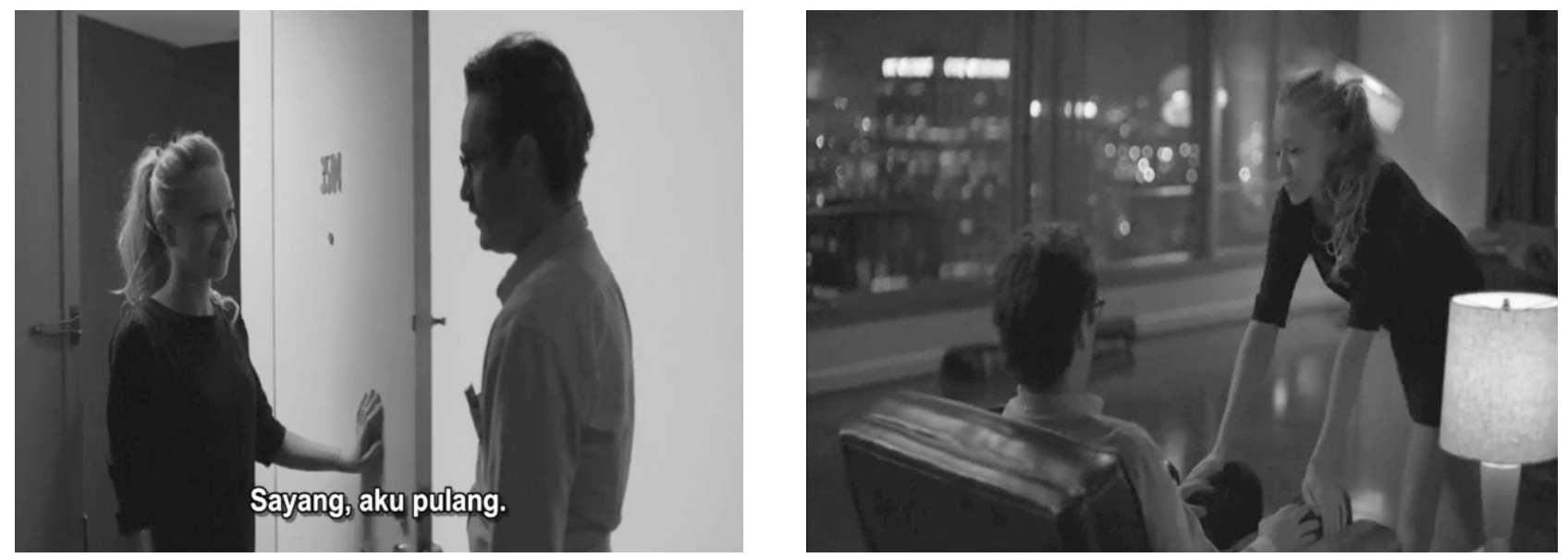

Gambar 9. Gadis yang bersedia meminjamkan tubuhnya atas inisiatif Samantha yang ingin merasakan bagaimana mempunyai tubuh selayaknya manusia
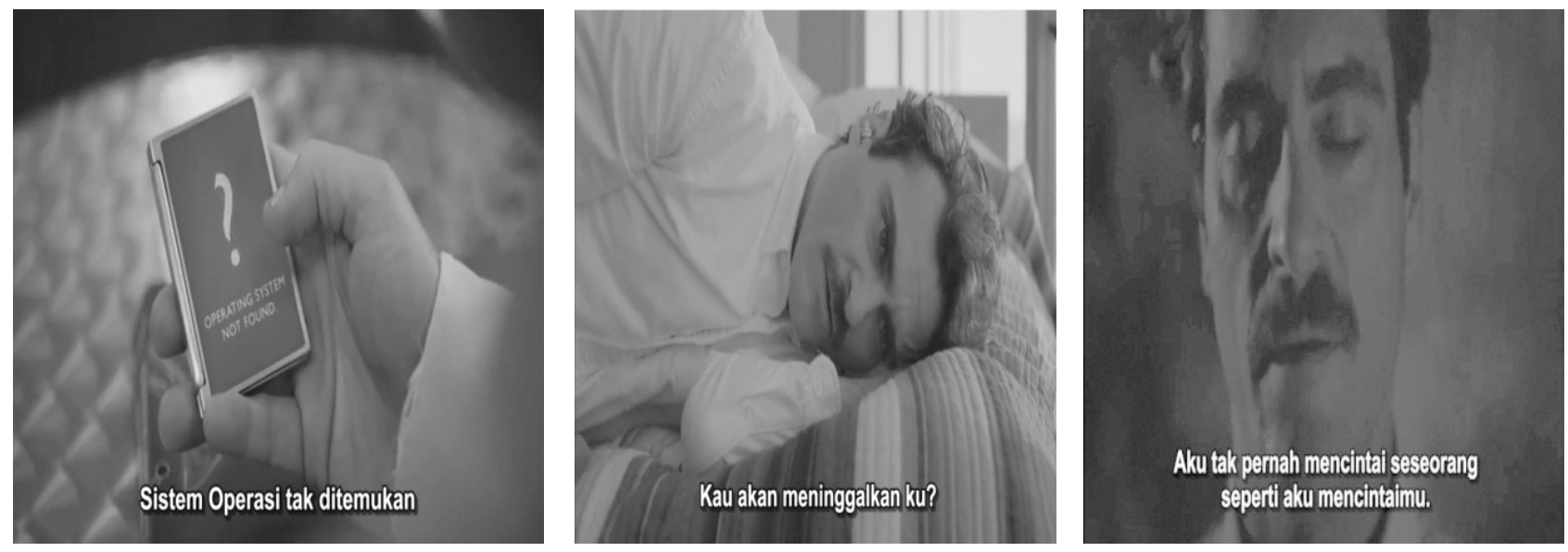

Gambar 10-12. Ketika komunikasi sudah tidak bisa dipertahankan maka hubungan antara Samantha dan Theodore harus berakhir 


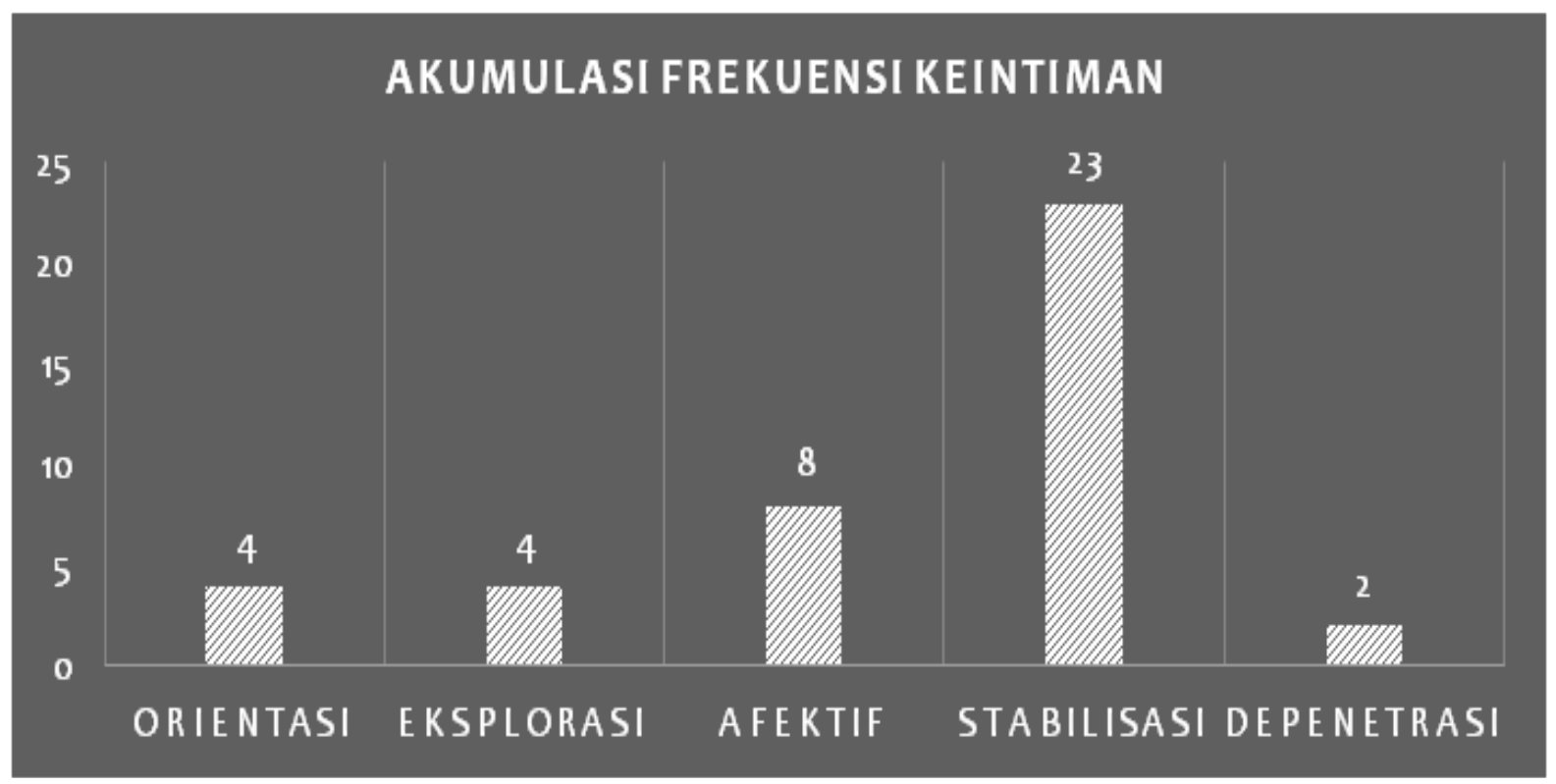

Grafik 1. Akumulasi frekuensi keintiman

Taylor dan pembentukan keintiman antarpribadi yang dikemukakan oleh Brent.

Penggambaran keintiman pada tingkat orientasi didominasi oleh topik pembicaraan yang normatif yang ditandai dengan adanya diskusi yang bersifat umum dan sederhana sebagai tahap awal dari suatu hubungan. Sebesar 50\% atau sebanyak dua kali kemunculan pada sequence 4 dan 5, topik pembicaraan normatif dimunculkan sebagai interaksi yang terbentuk antara Theodore dan Samantha pada urusan yang sifatnya profesional seperti asistensi pekerjaan. Kemudian pada urutan kedua dan ketiga dengan presentase masing-masing $25 \%$ adalah tegur sapa sederhana yaitu sapaan perkenalan yang umumnya dilakukan ketika pertama kali berjumpa dan komunikasi tertutup yang dicirikan dengan masih tersimpannya secara rapat hal-hal yang sifatnya personal dan rahasia.

Pada tingkat eksplorasi, topik pembicaraan yang menuju ke arah personal paling banyak muncul dengan persentase $75 \%$ dan $25 \%$ sisanya adalah komunikasi yang sifatnya sudah mulai terbuka. Penggambaran keduanya ditunjukkan pada sequence 7, 8, dan 10 ketika Theodore sudah mulai membuka diri melalui jawaban-jawaban yang dia berikan atas pertanyaan-pertanyaan yang menyinggung masalah pribadi yang mulai ditanyakan oleh Samantha. Pada situasi ini, keduanya tampak melakukan banyak eksplorasi dan penelusuran informasi untuk mengetahui satu sama lain lebih jauh.

Pada tingkat afektif, topik pembicaraan sudah menyentuh area pribadi dengan porsi yang lebih banyak dibandingkan dua tahapan sebelumnya. Adanya dominasi topik pembicaraan yang privat sebanyak empat kali kemunculan (50\%) akan diiringi dengan pengungkapan perasaan $(37,5 \%)$ satu sama lain. Theodore yang sudah sangat terbuka dan jujur kepada Samantha tentang dirinya telah memancing Samantha untuk melakukan hal yang sama, dan pada gilirannya hal tersebut diikuti dengan masuknya komunikasi ke wilayah intim $(12,5 \%)$ yang erat kaitannya dengan hasrat atau nafsu seksual. Dengan demikian, terpenuhinya ketiga unsur tersebut sangat memungkinkan terciptanya suatu status hubungan baru yang lebih akrab dan intim-Theodore dan Samantha akhirnya berkencan sebagai sepasang kekasih. Ketiga unsur afektif ini ditunjukkan secara berurutan mulai dari sequence 10 sampai 14 .

Pada tingkat stabilisasi, hubungan beralih ke arah yang lebih stabil dengan adanya ikatan status yang menyertainya. Topik yang dibicarakan pada tingkat ini masih bersifat personal namun dengan frekuensi yang lebih banyak atau lebih sering daripada pembicaraan personal yang ditemui pada tingkat afektif - terhitung ada 7 kali kemunculan topik pembicaraan personal pada tahap ini. Meski 
masih bersifat personal, intensivitas komunikasi pada tingkat ini ditemukan lebih dominan dengan 9 kali kemunculan. Hal ini ditonjolkan pada kian intensnya Theodore dan Samantha berkomunikasi satu sama lain. Kemudian, pengukuhan status hubungan muncul sebanyak 6 kali dan sebanyak 1 kali pengukuhan itu coba dibuktikan oleh keduanya melalui hubungan intim atau physical intercourse pada sequence 22.

Pada tingkat depenetrasi, komunikasi menjadi hilang kendali sehingga hubungan menjadi sulit untuk dipertahankan. Dua karakter utama dari fase ini adalah berkurangnya intensitas dan intensivitas komunikasi dua arah menjadi satu arah dan pemutusan status hubungan yang ditandai dengan perpisahan. Keduanya dimunculkan pada sequence 28 film dengan presentase kemunculan masing-masing sebesar 50\%.

Secara spesifik, berdasarkan 14 unit analisis yang ditetapkan dalam penelitian, dapat diketahui bahwa komunikasi intensif (22\%) mendominasi penggambaran keintiman dalam film, diikuti oleh topik pembicaraan personal dalam tahapan stabilisasi hubungan (17\%), pengukuhan status (15\%), topik pembicaraan personal dalam tahapan eksplorasi (10\%), pengungkapan perasaan (7\%), dan menyusul unit lainnya pada presentase $2 \%, 3 \%$, dan $5 \%$.

\section{KESIMPULAN}

Secara spesifik, penelitian ini tidak bertujuan untuk memahami atau mengilustrasikan pesan sosial yang ada di balik penceritaan film, oleh karenanya penelitian ini tidak dapat digunakan untuk melihat isi yang tidak tampak (latent). Konten yang tidak tampak atau tersembunyi hanya dapat dijelaskan dengan menggunakan analisis isi yang sifatnya kualitatif. Meskipun dalam konteks penelitian ini, penggabungan keduanya dimungkinkan, tetapi hal tersebut akan membuat fokus penelitian melebar sehingga tidak sesuai dengan maksud dan tujuan dari penelitian yang ingin menunjukkan kecenderungan umum yang objektif.

Secara umum, keintiman yang ditampilkan antara manusia dan komputer dalam film "Her" sepenuhnya memenuhi prinsip penetrasi sosial dan pembentukan hubungan interpersonal dalam kasus keintiman komunikasi. Meski belum tentu persis terjadi pada kehidupan nyata, tetapi film ini menjadi refleksi dari kenyataan sekarang bahwa manusia tidak bisa lepas dari teknologi atau yang lebih buruk lagi tergantung pada teknologi. Melalui film ini kita dapat memetik pelajaran berharga bahwa sebagai manusia haruslah mampu membentengi diri terhadap pengaruh teknologi yang tidak selamanya baik dan mendatangkan kemanfaatan. Kita seharusnya memahami bahwa kita mempunyai otonomi diri terhadap teknologi yang kita miliki. Jangan sampai teknologi mengambil alih seluruh kehidupan kita.

\section{DAFTAR PUSTAKA}

Baron, R.A., \& Byrne, D. E., (2004). Social pyschology. USA: Pearson.

Berelson, B. (1952). Content analysis in communication research. New York: Hafner Press.

Dietz-Uhler, B., Bishop-Clark, C., Howard, E. (2005). Formation of and ad"Her"ence to a self-disclosure norm in an online chat. Cyberpsychology \& Behavior, 8(2), pp. 114-120.

Griffin, E. (2012). A first look at communication theory (8th ed.). New York: McGraw Hill

Heyes, M. P. (2012). Development of a fundamental ' 19 -sequence model' of screenplay and narrative film structure. Journal of Screenwriting, 3(2), pp. 215-232

IMDB. (n.d.). Her awards. Retrieved from http://www. imdb.com/title/tt1798709/awards?ref_ $=$ tt_awd

Kroger, J. (2001). Identity development: Adolescene through adulthood. London: SAGE Publication.

Marcia, J. E., Matteson, D. R., Archer, S. L., \& Orlofsky, J. L. (1993). Ego identity: A handbook for psychosocial research. New York: Springer-Verlag.

McCarthy, A. (2009). Social penetration theory and facebook. USA: Farfield University.

Reeves, B., \& Nass, C. (1996). The media equation: How people treat computers, television, and new media like real people and places. London: Cambridge University Press.

Ruben, B. D. (1992). Communication and human behavior. New Jersey: Prentince-Hall.

Shaffer, D.R. (2005). Social and personality development (5th ed.). USA: Thomson Learning, Inc. 
West, R. \& Turner, L.H. (2010). Introducing communication theory (4th ed.). New York: McGraw-Hill.

Whitty, M. T. (2008). Revealing the 'real' me, searching for the 'actual' you: Presentations of self on an Internet sating site. Computers in Human Behavior, 24(4), pp. 1707-1723.
Yang, M., Yang, C., \& Chiou, W. (2010). Differences in engaging in sexual disclosure between real life and cyberspace among adolescents: Social penetration model revisited. Current Psychology, 29(2), pp. 144-154. 